\title{
特「集 「日常診療で役立つ睡眠学の知識」
}

\author{
認知症患者の睡眠の問題と対応

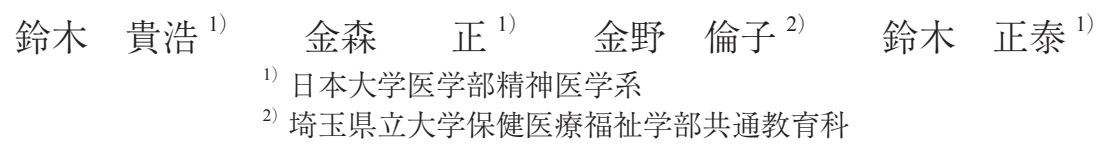

\author{
Sleep Disorders in Dementia and Their Management \\ Takahiro SuzukI $^{1)}$, Tadashi Kanamori ${ }^{1)}$, Michiko KonNo ${ }^{2)}$ and Masahiro Suzuki ${ }^{1)}$ \\ ${ }^{1)}$ Department of Psychiatry, Nihon University School of Medicine, Tokyo, Japan \\ ${ }^{2)}$ Center for University-wide Education, School of Health and Social Services, Saitama Prefectural University
}

\begin{abstract}
Sleep disorders are frequently observed in $40-60 \%$ of dementia cases. The complications of sleep disorders cause a decrease in the quality of life of patients and a burden on caregivers. It is clinically very important to address sleep disorders because they can be a factor in the worsening of behavioral and psychological symptoms of dementia. Sleep disorders in those with dementia are often caused by a combination of various factors and have complex pathologies, so they are difficult to treat. In this paper, we classify the factors associated with sleep disorders in dementia into three categories and describe how to address them in clinical practice.
\end{abstract}

Key words: dementia, insomnia, sleep disorders, behavioral and psychological symptoms of dementia, pharmacotherapy for insomnia/non-pharmacological intervention 認知症, 不眠, 睡眠障害, 認知症の行動・心理症状, 不眠に対する薬物療法・非薬物的介入

(J. Nihon Univ. Med. Ass., 2020; 79 (6): 349-352)

\section{はじめに}

認知症においては 40〜 60\%と高頻度に睡眠障害を認 める ${ }^{3)}$. 睡眠障害の合併は患者の QOL 低下を招くとと もに，介護者にとっても大きな負担となる。睡眠障害 以外の認知症に伴う行動及び心理症状 (behavioral and psychological symptoms of dementia: BPSD) の悪化要因と もなり得るため, その対応は臨床上極めて重要である. 認知症における睡眠の問題は多種多様な要因が絡み合っ て生じていることが多く複雑な病態を呈すため, 対応が 困難であることが多い，本稿では，認知症の睡眠障害の 要因を 3 つに整理・分類した上で，実臨床においてどの ように対応するかその方策について述べる.

\section{認知症における睡眠の問題}

臨床では夜間の睡眠困難（入眠困難，中途覚醒，早朝 覚醒）や昼夜逆転，日中に居眠りを繰り返す多相性睡眠 が問題となることが多く，これらは様々な要因によって 生じる。その要因は主として次の3つに分けられる (Fig. 1). 1）認知症症状の原因となっている脳障害が直接的 に睡眠調節機構に影響して引き起こされる睡眠障害,

2) 合併する BPSD や身体疾患等によって二次的に引き 起こされる睡眠障害，3）長時間の午睡や長く眠らせた いといった介護者の要請等を背景とした不適切な睡眠習 慣などの外部要因による睡眠の問題である.

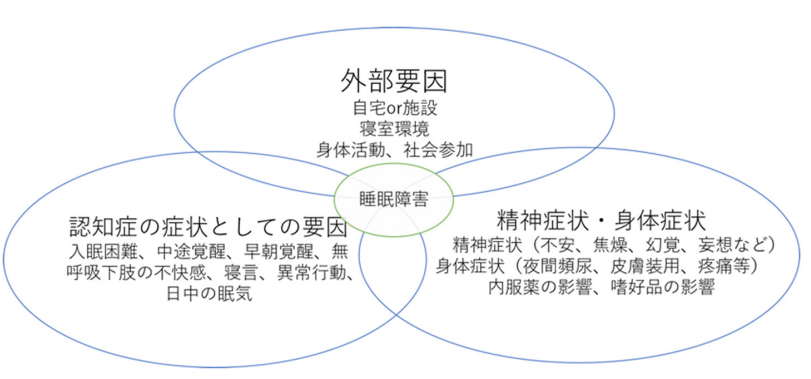

Fig. 1 Three factors constituting sleep disorders in dementia. (文献 3 より引用改変)

\section{1. 認知症症状の原因となっている脳障害が直接的に睡 眠調節機構に影響して引き起こされる睡眠障害}

認知症の原因疾患によらない共通する睡眠障害の特徵 は，中途覚醒が増加し概日リズムの振幅が低下すると いった睡眠の加齢性変化がより顕著に現れることであ る。それには, 認知症の神経病理が関連すると考えられ ている。

次に, 認知症の原因疾患別の睡眠障害の特徵を挙げる.

アルツハイマー病型認知症 (Alzheimer's disease: AD) では，体内時計の中枢である視交叉上核の神経細胞脱落 といった神経病理学的変化から, 概日リズムの振幅低 下，すなわち昼夜のメリハリが失われやすい4)。また， 睡眠の前半部で多く出現する徐波睡眠（深睡眠）が減少 しやすく，これについては内側前頭前皮質のアミロイド 
$\beta$ の増加と関連していると推測されている5).さらにア ミロイド $\beta$ の蓄積が徐波睡眠を障害するという悪循環を 生じ, 海馬依存的な記憶障害の増悪に関連すると考えら れている5).

レビー小体型認知症 (dementia with Lewy bodies: DLB) では日中の眠気や概日リズムの乱れが， $\mathrm{AD}$ と比べ高率 に生じる。脳幹に障害が及ぶとレム睡眠行動障害 (REM sleep behavior disorder: RBD) などの特徵的な睡眠障害を 認める。レム睡眠期における骨格筋の脱力が起こらなく なり (REM without atonia), 夢内容に従った寝言や叫び, 殴る蹴るといった激しい動きを認める。レム睡眠が朝方 に多く出現するため, RBD の症状を認めるのは朝方に 多い.レストレスレッグス症候群 (restless legs syndrome: RLS) ${ }^{6}$ や睡眠時無呼吸症候群 (sleep apnea syndrome: SAS) の合併も多い ${ }^{7)}$.

血管性認知症 (vascular dementia: VaD) では，発症早期 からせん妄や夜間の興奮, 夕暮れ症候群を伴うことが多 い。また，軽症例であっても意欲低下や自発性低下に よって活動量が低下しやすく, 昼夜のリズムが乱れ不眠 症状が出現しやすい.

\section{2. 合併する精神症状・身体症状による睡眠障害}

不安・焦燥等の BPSD が二次的に睡眠の悪化を引き起 こすことがしばしばある。また，一定以上の重症度の認 知症においては，夜間せん妄による昼夜逆転も高頻度に 認める。アパシーがある患者では，日中の活動性低下に より，生活のメリハリが失われやすく，睡眠と覚醒が不 規則となる。これは夕方から夜間にかけての興奮, 落ち つきのなさといったいわゆる“夕暮れ症候群”之関連す ると考えられている.

高齢者は複数の身体疾患の治療を受けている場合も あり, 呼吸器·循環器疾患に伴う呼吸困難感, 夜間頻尿, 皮膚掻痒感などが睡眠妨害要因となっていることがある。 服用中の薬，嗜好品の影響による不眠も少なくない。腎 障害や鉄欠乏によって RLS や RLS との合併が多い周期 性四肢運動障害 (periodic limb movement disorder: PLMD) などの睡眠障害が合併している可能性についても留意す る必要がある。 RLSでは, ベッドで横になって休もう としたときに強く感じられる下肢の異常感覚（「ムズム ズ」，「虫がはう感じ」などと表現される）が生じる。そ のため, 強い入眠困難が生じる。常に足を動かしたいと いう衝動にかられ，実際に足を動かすと症状が軽減する ため歩き回るなどの行動につながり，その他の夜間の行 動の障害との鑑別が必要である。PLMDでは，夜間睡眠 中に周期的な下肢のピクつき（足関節の背屈が母趾の背 屈, 膝関節の屈曲を伴って生じる）により睡眠が障害さ れる。患者が下肢のピクつきを自覚していないことがあ り，その場合は訴えが入眠困難，中途覚醒，日中の眠気 といった睡眠に関することのみとなるため，他者による
観察が診断の一助になることがある.

\section{3. 外部要因による睡眠の問題}

介護施設においては，消灯時間が 21 時から 6 時，も しくはそれよりも長く設定されていることが少なくない. 床上で眠らずに過ごす時間が長いと, 中途覚醒の増加や 浅眠化を引き起こすため注意が必要である。ヒトの睡眠 時間は加齢とともに生理的に減少し，65歳の健常高齢 者では平均 6 時間程度である ${ }^{8)}$ 。夜間の明かりや日中の 薄暗さも昼夜のメリハリをつけづらくさせる，夜間の不 眠の施設スタッフの配置などの制約のためやむを得ない 場合もあるが，より長い睡眠時間を求めると，さらに夜 間異常行動を助長しスタッフの負担，患者の負担の増大 につながることがある。

\section{認知症患者でみられる睡眠の問題への対応}

これまで述べてきたことを踏まえ，認知症における睡 眠の問題への対応について次に述べる。

\section{1. 治療可能な合併睡眠障害・睡眠に影響する身体状態 の評価}

睡眠に関して睡眠薬の投与等の直接的な対応に着手す る前に，まず行うべきことがある，他の睡眠障害，とく に治療可能な睡眠障害の合併の有無の評価である。 RBD やRLSなどを見逃し，不眠症として睡眠薬などの鎮静 系薬剤でこれらに対応しても改善が得られないどころか, むしろ転倒・骨折のリスク増大，認知機能障害の悪化を 招く。夜間の睡眠困難や日中の居眠りがこれらの睡眠障 害によって生じ，患者の認知機能へ影響する場合もある ため，その鑑別は重要である。

DLBでは，RBDをしばしば認める。この場合，少量 のクロナゼパムで改善が期待できる。せん妄との鑑別が 問題になるが, RBD では覚醒させることが可能であり， 覚醒後に行動と関連した夢内容を想起できる点が，意識 障害であるせん妄とは異なり鑑別のポイントとなる。ま た，DLB やパーキンソン病，脳血管障害では，RLS や PLMD を認めることが多い，鉄欠乏や腎機能障害を背景 に生じていることも多く，これらを評価し原疾患の治療 を進めることが肝要である，RLSやPLMDを惹起しう る身体状態がない場合やその改善が困難な状況において は，各患者の身体状態を勘案した上で，プラミペキソー ルやロチゴチン，ガバペンチンエナカルビル等の使用を 検討する。

SAS はAD では 40〜 70\% と高率に合併し9， VaD でも 頻度が高いといわれる。夜間睡眠の分断化，日中の眠気 などに大きく関与する。閉塞型 SAS では持続陽圧呼吸 療法が行われることが多いが，認知症患者では導入が困 難なことも多い. BZ 受容体作動薬等の舌根沈下を来た し悪化要因となりうる薬剤は極力使用しないようにする. 
せん妄が生じている場合には，背景にある身体因の評 価を行なった上で，非薬物的・薬物的介入によって改善 を試みる. BZ 受容体作動薬はせん妄を悪化させる可能 性があることから，薬物療法を行う場合には少量の非定 型抗精神病薬が選択されることが多い，身体疾患による 睡眠妨害要因（呼吸困難感，夜間頻尿，皮膚掻痒感な ど）についてもこの段階で評価し，その改善に努める。

\section{2. 非薬物的・薬物的介入}

\section{(1)非薬物的介入}

前述の治療可能な睡眠障害の合併や睡眠に影響する身 体状態の評価を行なった後に不眠症状やリズム障害への 対応を検討する。認知症患者では，代謝機能の低下，低 体重，様々な基礎疾患の合併から，薬物療法を行なった 際に有害事象が出現しやすい。有害事象のリスクを最小 限に留める必要からまず非薬物的介入を行い，それでも 改善が難しいと考えられる場合にのみ薬物療法を適宜非 薬物的介入と組み合わせて行う。

行動療法を含め様々なアプローチが推奨されているが, 非薬物的介入，薬物治療いずれにおいても現時点では明 確なエビデンスがあるとはいえないことについては留意 が必要である。

まず始めに睡眠習慣の見直しを行う。昼寝を最小限に して，定期的な身体的活動・社会的活動を行うことを目 標にする。デイサービスやデイケアの活用は，介護者の 負担を避けながら，昼夜のメリハリをつけることに有用 である。前述のように介護施設においては，生理的に必 要な睡眠時間よりも極端に長い床上時間（消灯時間）か 設定されていることが多い。施設での生活スケジュール を入所者の状態に合わせて再検討することは介護者負担 軽減にもつながる対応のひとつと考えられる。

認知症の不眠に対する高照度光療法 (bright light therapy: BLT) についていくつかの報告がある。睡眠潜 時, 総睡眠時間, 就床時間, 睡眠効率に対して有効であ $る^{10,11)}$ 。光は視交叉上核を刺激し，体内時計を環境のリ ズムへと同調を促す。夕方から失見当識・不稻・徘徊が 悪化する夕暮れ症候群などを示す症例においては，昼か ら夜に移行する時間帯，すなわち夕方の時間帯をより 明るくすることの有効性も指摘されている ${ }^{12)}$ ，通常 BLT では，卓上型や壁面・天井設置型の光照射装置を用いて 2,500〜10,000 lux の高照度光を照射するが，そのような 設備を有する施設は少ない。しかし，日当たりの良い場 所で過ごしていれば，睡眠・覚醒リズムを整えるのに十 分な光量を浴びることは可能であり，極力そのような場 所で過ごさせることが重要である.

\section{(2)薬物療法}

認知症の不眠症状に使用される薬物を Table 1（文 献）に示した。メラトニン受容体作動薬であるラメルテ
Table 1 Pharmacological and non-pharmacological treatments for sleep disorders in dementia.

\begin{tabular}{|c|c|}
\hline 非薬物療法 & 薬物療法 \\
\hline & メラトニン \\
睡眠衛生教育 & メラトニン受容体アゴニスト \\
身体的活動 & ベンゾジアゼピン \\
社会参加 & 非ベンゾジアゼピン系睡眠薬 \\
高照度光療法 & 鎮静系抗うつ薬 \\
& 抗認知症薬 \\
& オレキシン受容体拮抗薬 \\
\hline
\end{tabular}

文献 3 より引用改変.

オンは，体内時計に働きかけ体内環境を休息・睡眠に 適した状態にすることで自然な睡眠をもたらす。BZ 受 容体作動薬のようにGABA 神経系を介した大脳皮質に 対する直接的鎮静作用を持たず13)，記憶障害，筋弛緩， 反跳現象や依存が生じない。認知症においても安全に 使用できる薬剤と考えられるが，軽度から中等度の $\mathrm{AD}$ を対象に $8 \mathrm{mg}$ の眠前投与の効果を検証した臨床試験で は，プラセボと総睡眠時間に有意な差は認められなかっ た ${ }^{14)}$ 。一方で，認知症を伴うパーキンソン病の睡眠障害 に対する有効性，夕暮れ症候群に対する有效性に関する 症例報告が散見されている。また，DLBにおいては， ラメルテオンの投与により睡眠障害とともに他の BPSD も改善したという報告 ${ }^{15)}$ がある。不眠症状改善作用は 弱いと考えられるが，MT2 受容体への作用を介した概 日リズム変位作用から, 昼夜逆転が生じている症例には 有用な可能性がある。

オレキシン受容体拮抗薬であるスボレキサントは, 筋 弛緩作用が少なく，認知機能，呼吸機能への影響も少な いことから ${ }^{16)}$ ，認知症患者に対しても比較的安全に使用 できる睡眠薬と考えられる。認知症の不眠症状に対する 有効性の系統的な検討はなされていないが，実臨床にお いては，安全性の高さから使用されていることが多い.

$\mathrm{BZ}$ 受容体作動性睡眠薬は, 強い催眠作用を有するも のの, 日中の鎮静, 転倒・骨折, せん妄のリスクが高ま ることから，その使用については慎重である必要がある. また，睡眠時遊行症などの睡眠時随伴症を惹起すること があることにも注意が必要である ${ }^{17)}$ ，止むを得ず認知症 患者の不眠に使用する場合には，筋弛緩作用等がより少 ないとされるゾルピデム, ゾピクロン, エスゾピクロン などのいわゆる“z-drug”が選択される。

鎮静系抗うつ薬はその催眠作用から睡眠薬として処方 されることが多く, 特にトラゾドンは徐波睡眠を増やす ことから, 認知症者の睡眠治療において注目されている。 Camargos らはトラゾドンでは眠前 $50 \mathrm{mg}$ の服用で 40 分 以上総睡眠時間が延長し，有意な有害事象も認められな かった ${ }^{18)}$ と報告している.

BPSD に対する抗精神病薬投与については，錐体外路 症状，耐糖能異常その他の副作用に対する懸念から，あ 
るいはアメリカ食品医薬品局 (FDA) の報告から, 使用 については慎重になる, ないし控えることを推奨する向 きもある.しかし，最近ではランダム化されていないも のの頻回な中途覚醒が認められる $\mathrm{AD}$ に対してドネペジ ル 5〜10 mg に付加する形で，リスペリドン $0.5 \sim 1 \mathrm{mg}$, ゾルピデム 5〜10 mg, メラトニン $2.55 \mathrm{mg}$, 付加薬なし で比較したところ，5年後の睡眠評価で悪化が認められ なかったのはリスペリドン群のみであったという報告も ある19)

\section{おわりに}

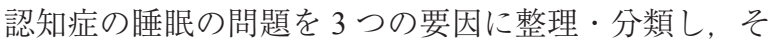
の対応について述べた。認知症の睡眠障害は多種多様で あり，重症度によっても対応が異なる。個別に問題を整 理・検討することが, 安全かつ適正に治療を行うために 重要である。

なお，本論文に関して，開示すべき利益相反関連事項 はない

\section{文献}

1) Merlino G, Piani A, Gigli GL, et al. Daytime sleepiness is associated with dementia and cognitive decline in older Italian adults: a population-based study. Sleep medicine 2010; 11: 372-377.

2) Rongve A, Boeve BF, Aarsland D. Frequency and correlates of caregiver-reported sleep disturbances in a sample of persons with early dementia. Journal of the American Geriatrics Society $2010 ; \mathbf{5 8}: 480-486$.

3）金野倫子. 認知症における不眠への対応・視点と方法. 睡眠医療 2018; 12: 513-521

4) Evans LK. Sundown syndrome in institutionalized elderly. Journal of the American Geriatrics Society 1987; 35: 101108.

5) Mander BA, Marks SM, Vogel JW, et al. $\beta$-amyloid disrupts human NREM slow waves and related hippocampus-dependent memory consolidation. Nature neuroscience 2015; 18: 1051-1057.

6) Bhalsing K, Suresh K, Muthane UB, et al. Prevalence and profile of Restless Legs Syndrome in Parkinson's disease and other neurodegenerative disorders: a case-control study. Parkinsonism \& related disorders 2013; 19: 426-430.

7) Pao WC, Boeve BF, Ferman TJ, et al. Polysomnographic findings in dementia with Lewy bodies. The neurologist 2013; 19: 1 .

8) Ohayon MM, Carskadon MA, Guilleminault C, et al. Metaanalysis of quantitative sleep parameters from childhood to old age in healthy individuals: developing normative sleep values across the human lifespan. Sleep 2004; 27: 1255-1273.

9) Ancoli-Israel S, Klauber MR, Butters N, et al. Dementia in institutionalized elderly: relation to sleep apnea. Journal of the American Geriatrics Society 1991; 39: 258-263.

10) Van Maanen A, Meijer AM, van der Heijden KB, et al. The effects of light therapy on sleep problems: a systematic review and meta-analysis. Sleep medicine reviews 2016; 29: 52-62.

11) Sekiguchi H, Iritani S, Fujita K. Bright light therapy for sleep disturbance in dementia is most effective for mild to moderate Alzheimer's type dementia: a case series. Psychogeriatrics 2017; 17: 275-281.

12) Khachiyants N, Trinkle D, Son SJ, et al. Sundown syndrome in persons with dementia: an update. Psychiatry investigation 2011; 8: 275.

13) Kato K, Hirai K, Nishiyama K, et al. Neurochemical properties of ramelteon (TAK-375), a selective MT1/MT2 receptor agonist. Neuropharmacology 2005; 48: 301-310.

14) McCleery J, Sharpley AL. Pharmacotherapies for sleep disturbances in dementia. Cochrane Database of Systematic Reviews 2020; 11

15）金野倫子．夜間の高笑いを伴う睡眠障害にメラトニン受 容体作動薬が奏効した 1 例。㸚むりと医療 2013；6: 24 26.

16）内村直尚，戸田康夫．Suvorexant の有効性と安全性．睡 眠医療 2014; 8(suppl): 515-521.

17) Iranzo A. Parasomnias and sleep-related movement disorders in older adults. Sleep medicine clinics 2018; 13: 51-61.

18) Camargos EF, Louzada LL, Quintas JL, et al. Trazodone improves sleep parameters in Alzheimer disease patients: a randomized, double-blind, and placebo-controlled study. The American Journal of Geriatric Psychiatry 2014; 22: 1565 1574.

19) Yin Y, Liu Y, Zhuang J, et al. Low-dose atypical antipsychotic risperidone improves the 5-year outcome in Alzheimer's disease patients with sleep disturbances. Pharmacology 2015; 96: $155-162$. 